\title{
Experimental Investigation on the Shape and Depth of Local Scour Hole Downstream of the Release Structure
}

\author{
Vouchleang Hong, Genguang Zhang*, Xinqiang Wang, Anbin Li \\ College of Water Resources and Architectural Engineering, Northwest A \& F University, Yangling, Shaanxi, China \\ Email: vouchleanghong@nwafu.edu.cn, *Zgg64@163.com
}

How to cite this paper: Hong, V., Zhang, G.G., Wang, X.Q. and Li, A.B. (2020) Experimental Investigation on the Shape and Depth of Local Scour Hole Downstream of the Release Structure. World Journal of Engineering and Technology, 8, 104-120. https://doi.org/10.4236/wjet.2020.81010

Received: January 17, 2020

Accepted: February 22, 2020

Published: February 25, 2020

Copyright $\odot 2020$ by author(s) and Scientific Research Publishing Inc. This work is licensed under the Creative Commons Attribution International License (CC BY 4.0).

http://creativecommons.org/licenses/by/4.0/

cc) (i) Open Access

\begin{abstract}
Local scour downstream of the release structure is a critical problem to the safe and stable operation of water resources and hydropower engineering. In order to investigate the shape and depth of the scour hole under the equilibrium state of erosion and deposition downstream of an apron, a group of 16 experiments from the hydraulic similarity model test of Dangka Hydropower Station was conducted with the non-cohesive sediment of different median particle sizes under different flow rates in this study. The control variable method was to study the influence of the flow rate and sediment size on the shape of the scour hole to define the number of experiment times of each test group. The results showed that the plane shape of the scour hole was irregular ellipse or semi-ellipse. The depth and size of the scour hole increased with the increase of the flow rate, and decreased with the increase of the sediment size; the downstream longitudinal slope ratio of the scour hole increased with the increase of the sediment size. The coefficients of the upstream and downstream slope ratio of the local scour hole were $1 / 2$ to $1 / 6$ and about $1 / 10$, respectively.
\end{abstract}

\section{Keywords}

Local Scour Downstream, Noncohesive Sediment Bed, Sediment Size, Flow Rate, Flow Pattern, Dangka Hydropower Station

\section{Introduction}

After the construction of the hydraulic structure on the river, the change of the characteristics of the natural river channel results in the increase of the water level difference between the upper and lower reaches. In the process of flood discharge, the constraint of buildings narrows the width of flood discharge pro- 
ducing the impact area of flood discharge more concentrated, which can cause erosion downstream of the release structure and even endanger the safety of buildings [1]. The large energy, the poor impact resistance downstream riverbed cover, and the high-strong turbulent flow velocity downstream of the hydropower will cause erosion on the riverbed, serious local scouring and scouring along the downstream channel, which poses a serious threat to the safety of the hydraulic structure and the banks [2] [3] [4] [5].

Accurate forecasting of the local scour downstream can not only avoid huge economic losses but also provide security for downstream towns, residents, ecological environment and enterprises. With the continuous growth of hub construction, the research on the relevant laws of scouring deformation under the hub dam has become more and more urgent [6] [7] [8] [9] [10]. Better predicting the impact on the river after the completion of the dam is a prerequisite for better service for the construction and national economy. The scouring deformation downstream of the dam has many influencing factors and complicated interrelationships [11] [12] [13] [14]. It is needed to consider the shear stress and shear flow [15] [16]. Additionally, the effect of flow and grain size on scour hole through various types of hydraulic structures is also a critical problem causing disaster [17] [18] [19]. The problem of previous research is greatly simplified. However, nowadays it is still difficult to calculate the shape of the scour, the maximum scour depth, and so on. Hence, some projects are sometimes destroyed by floods and cause various losses. For complex hydraulic problems, it often requires physical model testing.

The study of discharge flow, flow field, water level and pressure of the drainage structure of low-head hydropower station is well done previously [20] [21] [22]. Adduce has investigated on 1D-numerical and experimental studies of local scour downstream of a sill bed in clear water after a rigid apron [23]. The prediction of scour profiles and experiment tests have a better agreement for the higher discharges. The densimetric Froude number is an important factor expressing the equilibrium scouring characteristics no matter how the tailwater depth of the no protection apron is. Espa has investigated the experimental study on the local scouring of a sand bed and also used the densitometric Froude number, the normalized apron length, and the normalized tail-water depth to predict the flow regime after apron but ignored the effect of the Reynolds number and the sediment grain size [24]. The detail describing the three scouring regimes (surface jet, bed jet, and bed-surface jet scouring regimes) of the apron can be found in [25].

Based on the comprehensive analysis of relevant literature, the evaluation of the effect of flow through the release structure on the local scour downstream is necessary before the construction of hydropower. The experimental methods above predicted well the flow fields and the local scour downstream. Therefore, this paper includes the 16 groups of the hydraulic similarity model test of Dangka Hydropower Station under clear water to accurately predict the shape of the scour and observe scour the maximum depth of Dangka hydropower station and 
to provide strong technical support for water conservancy and hydropower construction. Moreover, it is to study the effect of the flow rate and the sediment size on local scour downstream of Dangka hydropower station.

\section{Experimental Setup}

Dangka Hydropower Station, a type of post-earthquake, is located in the middle of the Ziquriver in Dangka Village, Yushu County, Gansu Province, China. It is the fourth cascade hydropower station in the planning of the Ziqu River Basin. The main task of the station is power generation with a total installed capacity of $12 \mathrm{MW}$. This station has a total storage capacity of $10.9 \mathrm{million} \cdot \mathrm{m}^{3}$, a normal water storage level of $3848.00 \mathrm{~m}$ and a dead water level of $3846.00 \mathrm{~m}$. The dam crest elevation is $3849.00 \mathrm{~m}$ and the maximum dam height is $24.11 \mathrm{~m}$. The upstream slope of the dam is protected by the concrete precast block with a slope of 1:2.0 and a downstream slope of 1:1.75 [26].

The 16 groups of experimental data from the hydraulic similarity model test of Dangka Hydropower Station, studied the influence of flow rate and sediment size on morphology was conducted in the Sediment Laboratory of the College of Water Conservancy and Construction Engineering, Northwest A\&F University. The main buildings include: right bank gravity retaining water dam, riverbed plant, overflow dam, flood gate, left bank gravel dam, etc. The overall layout of the Dangka Hydropower Project Hub arranged from the left to the right, respectively, includes the $310.07 \mathrm{~m}$ long of barrage, the $13 \mathrm{~m}$ length of a single hole $7 \mathrm{~m}$ $\times 6.6 \mathrm{~m}$ of the floodgate, $12.30 \mathrm{~m}$ length of overflow dam, $35.50 \mathrm{~m}$ length of riverbed plant, $16 \mathrm{~m}$ length of installation interval and $38.20 \mathrm{~m}$ length of the right bank concrete auxiliary dam. After the model test, the optimized floodgate sluice chamber section is $32 \mathrm{~m}$ long in the upstream and downstream direction, and the net width of the sluice is $7 \mathrm{~m}$. The drainage structure is set as a flat-bottom floodgate on the main river bed where the elevation of the inlet floor of the flood sluice gate is determined to be $3824.50 \mathrm{~m}$ and the end of the chamber is connected with the bottom of the stilling basin by an arc. The length of the stilling basin is $48 \mathrm{~m}$ where the elevation of the bottom is $3818.5 \mathrm{~m}$ and the net width of the stilling pool section is $11 \mathrm{~m}$. The detail description of Dangka hydropower station scheme is illustrated in Figure 1.

The model uses a geometric scale of 1:50 and the other scales are as follows in Table 1 . The hydraulic model is designed according to the geometric similarity of water flow, similar gravity, and similar resistance. For the water flow through the hub, the force is mainly gravity, therefore the model is designed according to the gravity similarity criterion. The sidewall of the model river is brick-built. The topography of the upstream reservoir area is made into a fixed bed according to the original topographic map and plastered with cement mortar. The hinge parts such as the overflow meter hole and the flood discharge are all reduced by the scale of the prototype and made of plexiglass, see in Figure 2.

In order to more clearly determine the factors affecting the shape of the scour hole formed by the local scouring downstream of Dangka hydropower station, 


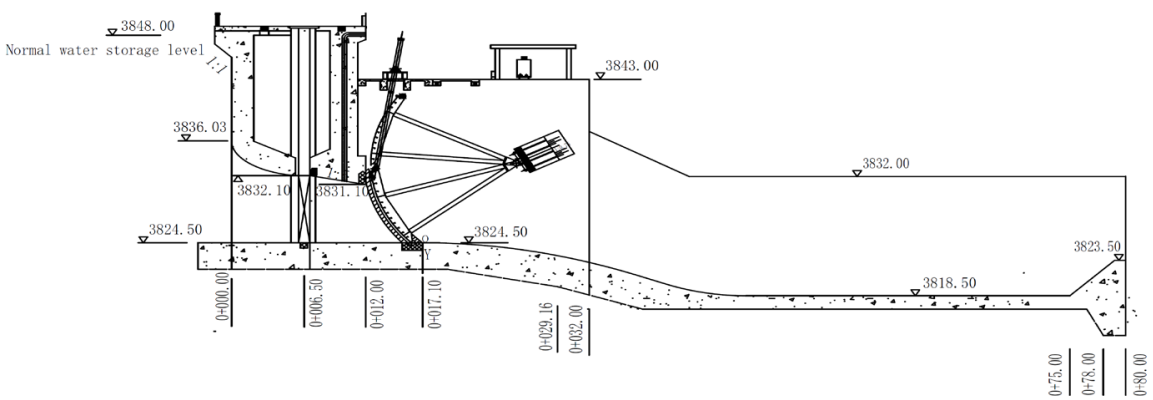

Figure 1. Longitudinal cross-section of Dangka hydropower station.

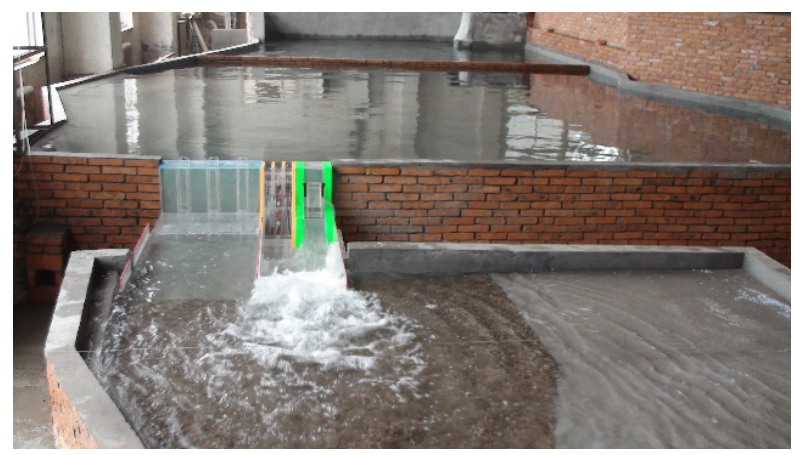

Figure 2. The overall experimental layout of Dangka hydropower station.

Table 1 . The similarity ratio of hydraulic model test.

\begin{tabular}{cccccc}
\hline Type & Model geometry & Flow velocity & Flow rate & Time & Roughness \\
\hline Ratio & 50 & 7.07 & 17678 & 7.07 & 1.92 \\
\hline
\end{tabular}

Table 2 presents the control variable method to test the influence of the flow rate and sediment size on the shape of the scour hole where the first column below shows the number of experiment times of each test group with 4 types of flow rate and 4 types of sediment size. In order to facilitate the test of water release and calculation, the flow and sediment sizes are all under the conditions of the prototype.

In each test, the sediment was placed and leveled with a steel ruler in the test section of the downstream reservoir after the stilling basin. The flow rate was adjusted by the upstream water level required. After the flow is stable, the formation process of the scouring downstream was observed to conduct relevant data measurement. According to the range of the scouring under different conditions, the important data were collected at the different measuring sections included end section of the apron, the maximum depth section of scour hole, the end section of scour hole, the several points in each section, the centerline of the section, the longitudinal velocity of the left, middle, and right walls, the water depth at the end of the apron, and so on. After the scouring was stabilized, downstream water was released and the scouring downstream terrain was observed and drawn as the topographic map of the scour under different working 
Table 2. The detail of experimental test groups of different flow rates over the various sediment size.

\begin{tabular}{ccc}
\hline Test times & ${\text { Flow } \text { rate }^{1}\left(\mathrm{~m}^{3} / \mathrm{s}\right)}$ & Sediment $\operatorname{size}^{1}(\mathrm{~mm})$ \\
\hline 1 & 400.48 & 500 \\
2 & 345.36 & 500 \\
3 & 291.34 & 500 \\
4 & 249.46 & 500 \\
5 & 400.48 & 300 \\
6 & 345.36 & 300 \\
7 & 291.34 & 300 \\
8 & 249.46 & 300 \\
9 & 400.48 & 100 \\
10 & 345.36 & 100 \\
11 & 291.34 & 100 \\
12 & 249.46 & 100 \\
13 & 400.48 & 50 \\
14 & 345.36 & 50 \\
15 & 291.34 & 50 \\
16 & 249.46 & 50 \\
\hline
\end{tabular}

${ }^{1}$ The values of flow rate and sediment size are shown in prototype size.

conditions. A high-precision level and a scale with a millimeter-scale were used to measure the scouring topography by using the measured zero elevation as the reference point. Then, use the benchmark to measure the elevation of the measuring point in the scour hole one by one. Finally, the elevation of the measuring point was converted into a relative elevation according to the zero elevation. In this way, the terrain image of the scour can be described with high precision and can reach $0.1 \mathrm{~mm}$. The role of the cord was to depict a topographical view of the scour formed by the flushing.

\section{Results and Analysis}

\subsection{Flow Pattern at the End of Apron}

Figure 3(a) and Figure 3(b) show the flow pattern of the outflow water at the flow rates of $400.48 \mathrm{~m}^{3} / \mathrm{s}$ and $291.34 \mathrm{~m}^{3} / \mathrm{s}$, respectively. The flow pattern at the end of apron has a very important effect on the morphology of the scouring hole. The flow pattern of the water flow at the end of the apron flowing to the river bed is not the same and the vertical flow pattern of the water flow is also different, thus the impact on the slope of the scour is also different. The greater the flow velocity at the bottom of the water flow, the greater the flow velocity gradient of the water flow in the boundary zone, which will result in a larger depth of the scour and a steeper slope. It is very important to take out the flow pattern of the water tank to check the shape of the scour hole. The reason why the flow pattern at the end of the apron can affect the shape of the scour hole is 


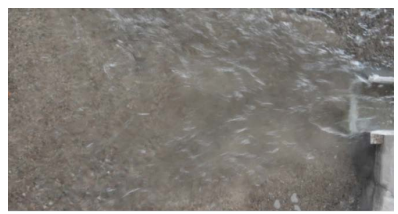

(a)

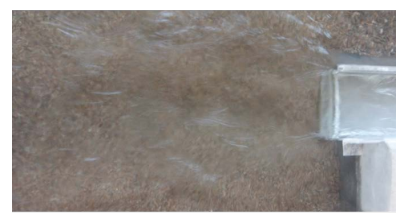

(b)

Figure 3. The mainstream flow through apron of $\mathrm{Q}=400.48$ $\mathrm{m}^{3} / \mathrm{s}(\mathrm{a})$, and $\mathrm{Q}=291.34 \mathrm{~m}^{3} / \mathrm{s}(\mathrm{b})$.

that the velocity and direction of the outflow changes. Comparing the flow patterns at the end of apron in the test under different flow rates, it is found that when the flow rate is large (Figure 3(a)), the mainstream flow through apron is more obvious and there is more obvious back-vortex flow on both sides of the mainstream.

Based on this conjecture, the Froude numbers of the water flow at the end of the apron under each working condition were compared in Table 3. Froude numbers are almost the same in the same flow rate even though the sediment size changes. It can be concluded that when the Froude number at the end of the apron is similar, the slope of the scouring downstream hole is also similar. Table 4 records the velocity of the end of apron under certain conditions. In order to ensure that the measured flow velocity at the end of apron is accurate and reliable, the flow velocity at the end of apron in each group of experiments was recorded. The result shows that the difference of Froude number of the flow in different sediment size group tests is very small at the same flow rate, so the flow pattern at the end of apron is basically the same.

\subsection{Influence of Flow Rate on the Shape of the Scour}

Topographic maps of $500 \mathrm{~mm}$ sediment sizes at $400.48 \mathrm{~m}^{3} / \mathrm{s}, 345.36 \mathrm{~m}^{3} / \mathrm{s}, 291.34$ $\mathrm{m}^{3} / \mathrm{s}$, and $249.46 \mathrm{~m}^{3} / \mathrm{s}$ of flow rates are illustrated in Figures $4(\mathrm{a})$-(d), respectively. The elevation is marked on the top line. For the convenience of measurement records, the reference elevation in the model of Dangka Hydropower Station was used as the reference. The actual value cannot be reflected here. The scour topographic map of the other three types, $300 \mathrm{~mm}, 100 \mathrm{~mm}$, and $50 \mathrm{~mm}$ of sediment size at each flow rate is shown in Figures 5-7, respectively. It can be seen from the above figures that under the same sediment size condition, the depth and range of the scour were decreasing with the decrease of the discharge flow. Therefore, in general, the larger the discharge flow rate, the larger the range of the scour downstream, and the deeper the scour. When the difference of flow rates was small, the crater may be slightly shallower under the large flow.

In order to more intuitively observe the variation of the depth and range of the scour at different discharge flows, the cross-section from the direction of the vertical channel of the scour and the longitudinal section along the channel is illustrated in Figure 8 where $\mathrm{Q}_{1}, \mathrm{Q}_{2}, \mathrm{Q}_{3}$, and $\mathrm{Q}_{4}$ representing $400.48 \mathrm{~m}^{3} / \mathrm{s}, 345.36$ $\mathrm{m}^{3} / \mathrm{s}, 291.34 \mathrm{~m}^{3} / \mathrm{s}$, and $249.46 \mathrm{~m}^{3} / \mathrm{s}$, respectively. It indicates the cross-sectional view of the scour hole under the four flow rates when the median sediment sizes 
Table 3. Froude numbers of water flow at the end of the apron under different working condition.

\begin{tabular}{ccc}
\hline $\mathrm{D}(\mathrm{mm})$ & $\mathrm{Q}\left(\mathrm{m}^{3} / \mathrm{s}\right)$ & $\mathrm{Fr}$ \\
\hline 500 & 400.48 & 0.25 \\
500 & 345.36 & 0.25 \\
500 & 291.34 & 0.24 \\
500 & 249.46 & 0.23 \\
300 & 400.48 & 0.25 \\
300 & 345.36 & 0.25 \\
300 & 291.34 & 0.23 \\
300 & 249.46 & 0.22 \\
100 & 400.48 & 0.25 \\
100 & 345.36 & 0.25 \\
100 & 291.34 & 0.23 \\
100 & 249.46 & 0.23 \\
50 & 400.48 & 0.26 \\
50 & 345.36 & 0.25 \\
50 & 291.34 & 0.24 \\
50 & 249.46 & 0.23 \\
\hline
\end{tabular}

Table 4. The velocity of the end of apron under certain conditions.

\begin{tabular}{|c|c|c|c|c|}
\hline \multirow{2}{*}{$\begin{array}{c}\mathrm{Q} \\
\left(\mathrm{m}^{3} / \mathrm{s}\right)\end{array}$} & \multirow{2}{*}{ Measuring position/(distance from the end of the water) } & \multicolumn{3}{|c|}{ Velocity/(m/s) } \\
\hline & & left & middle & right \\
\hline \multirow{7}{*}{400.48} & surface & 3.19 & 3.31 & 3.84 \\
\hline & $2 \mathrm{~cm}$ below the water & 3.59 & 3.81 & 4.29 \\
\hline & $4 \mathrm{~cm}$ below the water & 4.08 & 4.11 & 4.81 \\
\hline & $6 \mathrm{~cm}$ below the water & 4.36 & 4.63 & 5.54 \\
\hline & $8 \mathrm{~cm}$ below the water & 5.09 & 5.43 & 6.14 \\
\hline & $10 \mathrm{~cm}$ below the water & 5.61 & 6.02 & 6.57 \\
\hline & bottom & 6.74 & 7.13 & 6.24 \\
\hline \multirow{7}{*}{345.36} & surface & 3.36 & 3.22 & 3.59 \\
\hline & $2 \mathrm{~cm}$ below the water & 4.14 & 3.43 & 3.93 \\
\hline & $4 \mathrm{~cm}$ below the water & 3.93 & 3.74 & 4.4 \\
\hline & $6 \mathrm{~cm}$ below the water & 4.33 & 4.14 & 4.98 \\
\hline & $8 \mathrm{~cm}$ below the water & 4.45 & 4.45 & 5.67 \\
\hline & $10 \mathrm{~cm}$ below the water & 5.02 & 5.58 & 5.87 \\
\hline & bottom & 5.53 & 5.8 & 5.95 \\
\hline \multirow{6}{*}{291.34} & surface & 3.22 & 2.82 & 3.54 \\
\hline & $2 \mathrm{~cm}$ below the water & 3.36 & 3.06 & 3.89 \\
\hline & $4 \mathrm{~cm}$ below the water & 3.14 & 3.32 & 4.07 \\
\hline & $6 \mathrm{~cm}$ below the water & 3.67 & 3.64 & 4.15 \\
\hline & $8 \mathrm{~cm}$ below the water & 3.7 & 4.07 & 4.7 \\
\hline & bottom & 4.79 & 4.81 & 4.41 \\
\hline \multirow{6}{*}{249.36} & surface & 2.58 & 2.39 & 3.42 \\
\hline & $2 \mathrm{~cm}$ below the water & 2.46 & 2.76 & 3.54 \\
\hline & $4 \mathrm{~cm}$ below the water & 2.45 & 3.1 & 4 \\
\hline & $6 \mathrm{~cm}$ below the water & 2.88 & 4.04 & 4.04 \\
\hline & $8 \mathrm{~cm}$ below the water & 3.39 & 3.55 & 4.26 \\
\hline & bottom & 3.96 & 4.33 & 3.67 \\
\hline
\end{tabular}




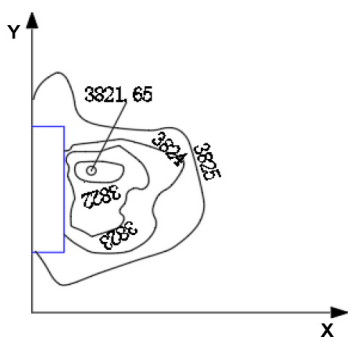

(a)

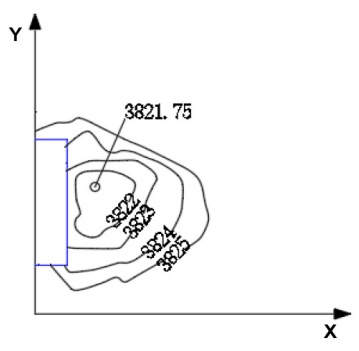

(b)

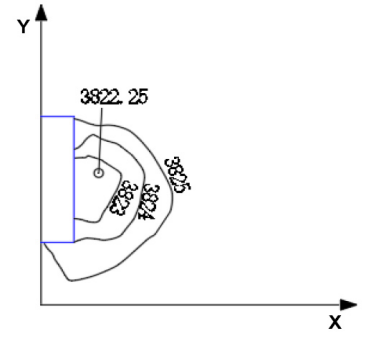

(c)

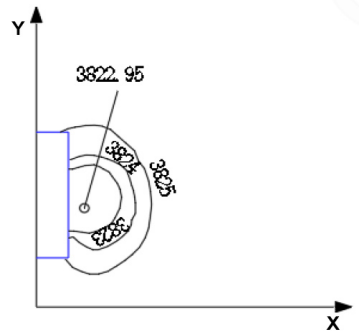

(d)

Figure 4. The contours of local scour downstream of $\mathrm{d}=500 \mathrm{~mm}$ under each flow in the stable stage.

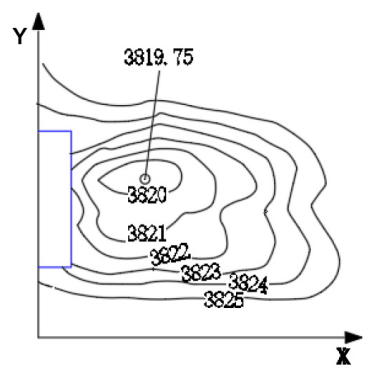

(a)

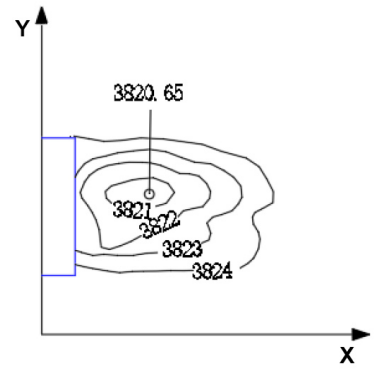

(b)

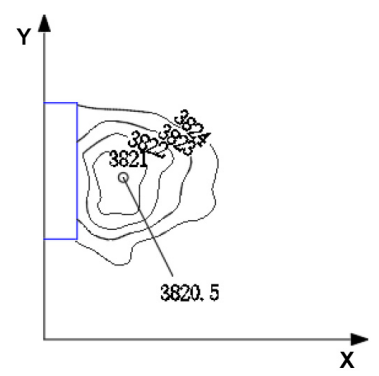

(c)

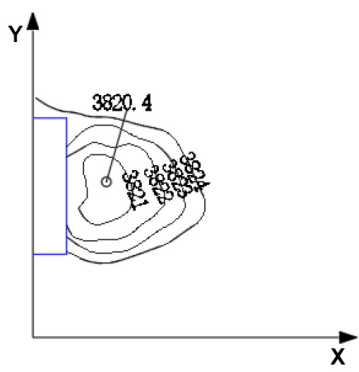

(d)

Figure 5. The contours of local scour downstream of $d=300 \mathrm{~mm}$ under each flow in the stable stage.

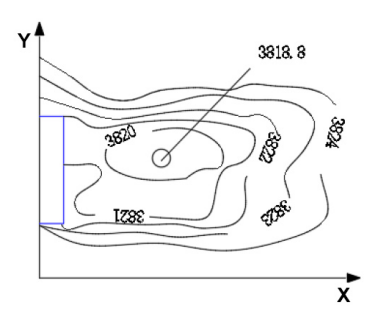

(a)

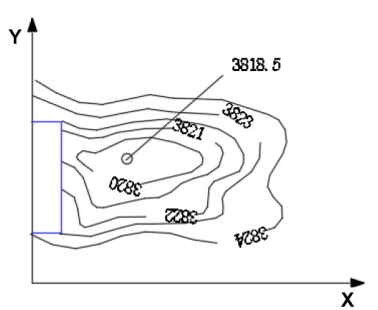

(b)

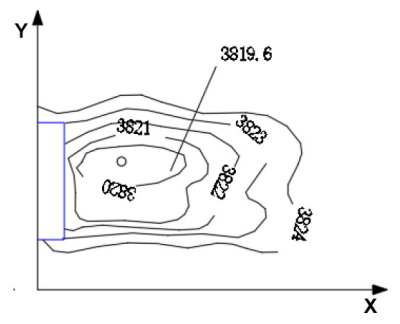

(c)

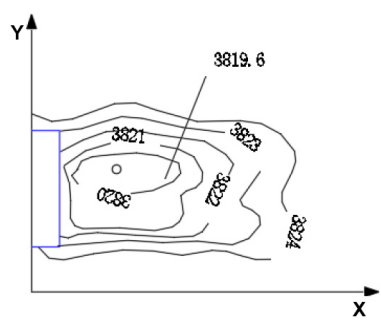

(d)

Figure 6. The contours of local scour downstream of $\mathrm{d}=100 \mathrm{~mm}$ under each flow in the stable stage.

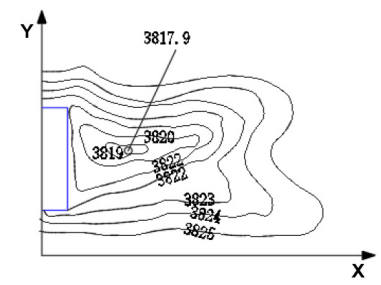

(a)

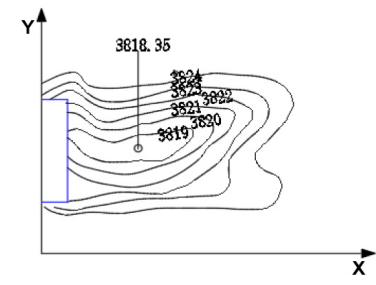

(b)

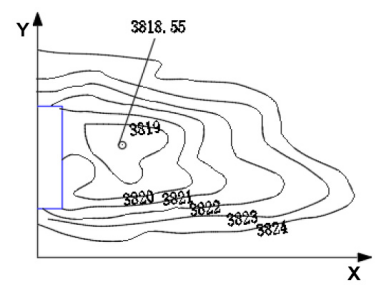

(c)

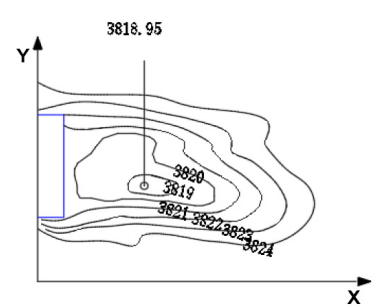

(d)

Figure 7. The contours of local scour downstream of $d=50 \mathrm{~mm}$ under each flow in the stable stage.

are $500 \mathrm{~mm}, 300 \mathrm{~mm}, 100 \mathrm{~mm}, 50 \mathrm{~mm}$, respectively. The horizontal coordinate of the figure is the coordinate zero point of the right edge of the scour hole, which is determined according to the measured distance, and the ordinate is the deepest scour depth as the coordinate zero point. It can be seen from the cross-sectional view that as the flow rate increases, the depth and lateral range of the scour basically increase. However, when the sediment size is large, the 


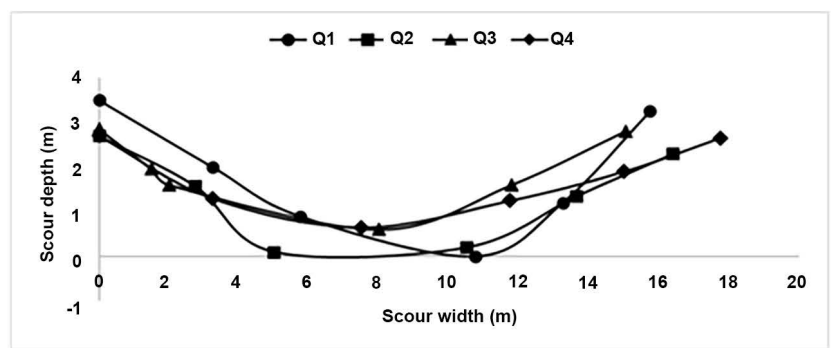

(a)

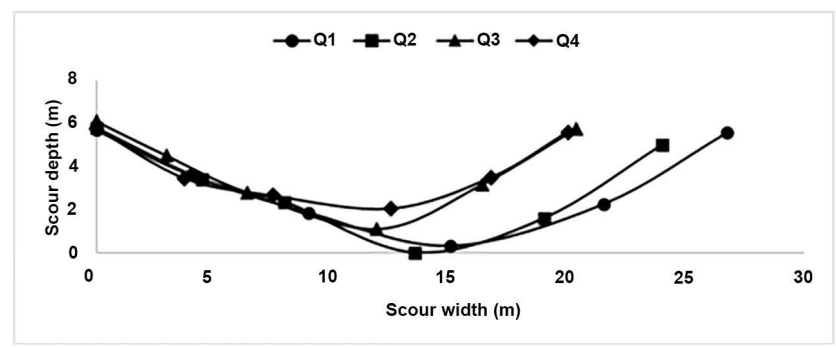

(c)

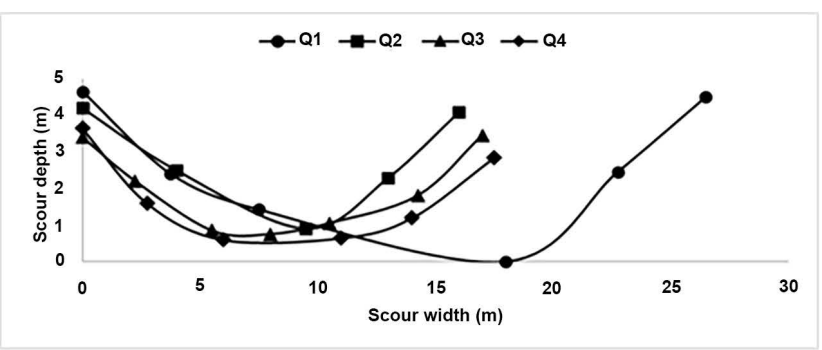

(b)

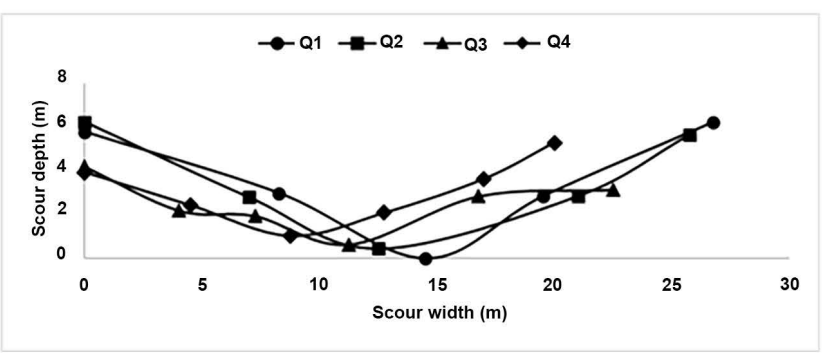

(d)

Figure 8. Cross-section of local scour downstream under different flow of $\mathrm{d}=500 \mathrm{~mm}$ (a), $300 \mathrm{~mm}$ (b), $100 \mathrm{~mm}$ (c), and $50 \mathrm{~mm}$ (d).

variation range of the cross-section is small, and even in the case of the small flow rate, the cross-sectional range is larger than the larger flow rate, as shown in Figure 8(a) and Figure 8(b). Comparing Figure 8(c) and Figure 8(d), when the sediment size is small, the larger the flow rate, the larger the lateral scouring range, which indicates the phenomenon in Figure 6 and Figure 7. The flow rate in the experiment is small relative to the sediment size caused by the phenomena in (a) and (b), resulting in a less obvious rule of lateral scouring. Therefore, the factors affecting the lateral scouring range are mainly hydraulic conditions and geological conditions. At the same time, it can be seen in the figures that the lateral scouring is relatively symmetrical because the lateral diffusion of the water flow at the end of the apron is relatively uniform.

Figure 9 and Figure 10 show the left and right longitudinal section of the scour at the four flow rates when the sediment size is $500 \mathrm{~mm}$ (a), $300 \mathrm{~mm}$ (b), $100 \mathrm{~mm}$ (c), and $50 \mathrm{~mm}$ (d). The abscissa of Figure 9 and Figure 10 is the coordinate zero point at the end of the apron (based on the measured distance in $\mathrm{cm}$ in the model). The ordinate is the elevation of the deepest scour as the coordinate zero. The right longitudinal profile is compared with the left longitudinal profile because from the topographical map Figures 4-7, it can be seen that the scour hole formed in the experiment basically has the left and right pit back slopes. The following two rules can be seen from the four figures of the left longitudinal scour in Figure 9. Under the same sediment size, the depth and longitudinal scour increase with the increase of the flow rate, which is mainly due to the large flow of water flowing out of the mainstream through the stilling basin. Moreover, the deepest points of the scour hole formed by the same sediment size at different flow rates are relatively close. 


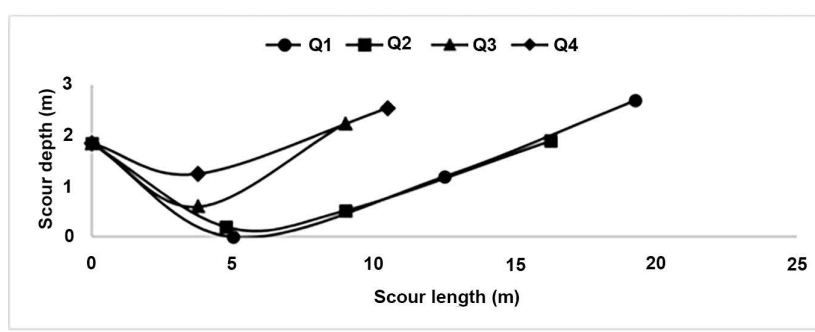

(a)

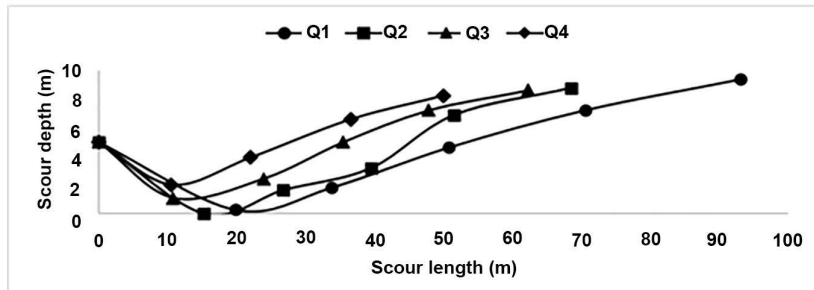

(c)

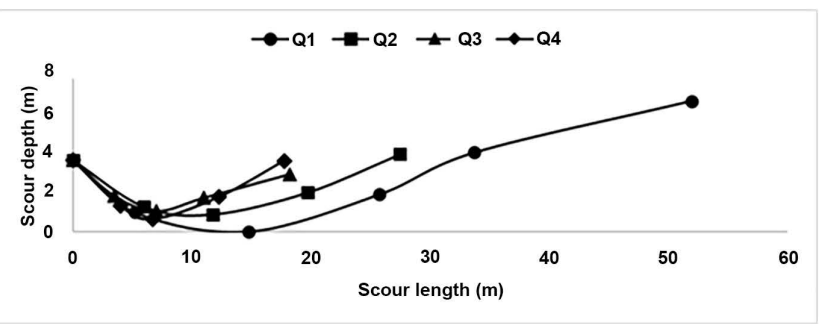

(b)

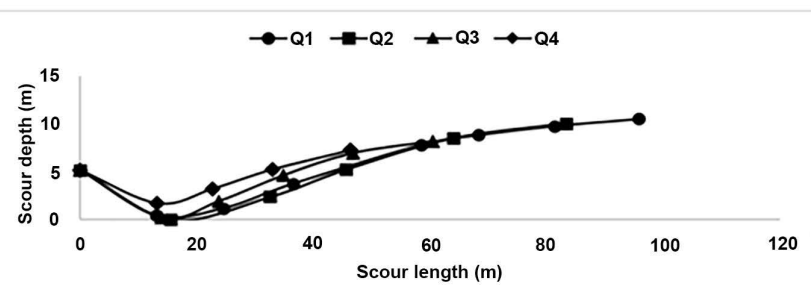

(d)

Figure 9. Left longitudinal profile of scour under different flows of $d=500 \mathrm{~mm}(\mathrm{a}), 300 \mathrm{~mm}(\mathrm{~b}), 100 \mathrm{~mm}$ (c), and $50 \mathrm{~mm}$ (d).

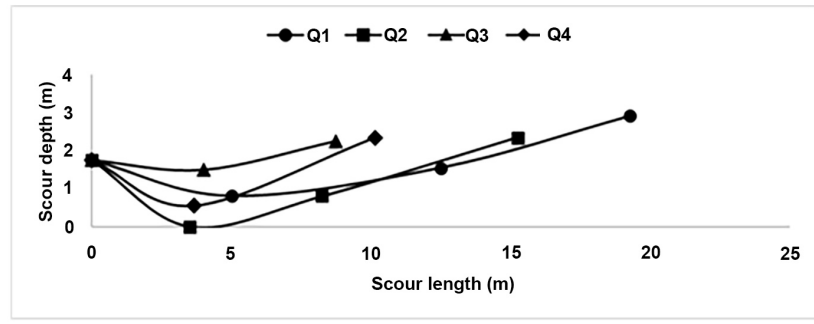

(a)

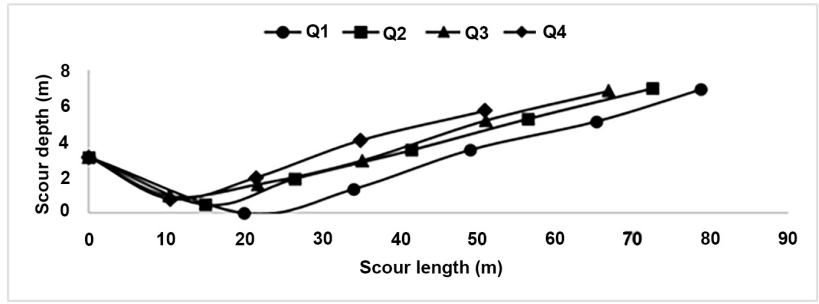

(c)

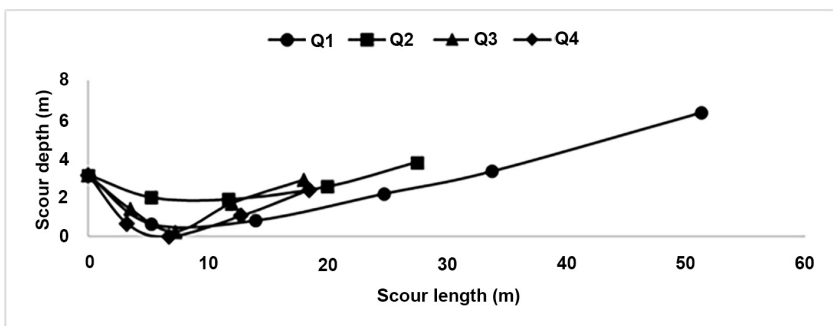

(b)

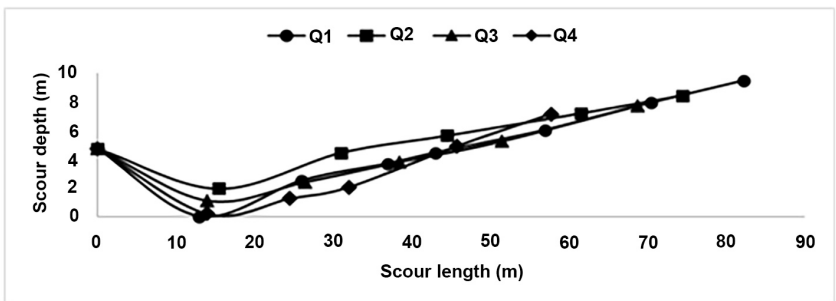

(d)

Figure 10. Right longitudinal profile of scour under different flows of $\mathrm{d}=500 \mathrm{~mm}$ (a), $300 \mathrm{~mm}$ (b), $100 \mathrm{~mm}$ (c), and $50 \mathrm{~mm}$ (d).

In Figure 9 and Figure 10, when the same sediment size is formed under different flow rates, the upstream and downstream slopes of the scour hole under different flow rate are very similar. The cause of this phenomenon should be related to the flow velocity (v) at the end of the apron, the water depth at the end of the apron (h), and the median particle size of the sediment $\left(\mathrm{d}_{50}\right)$.

\subsection{Influence of Sediment Size on the Shape of Scour}

In order to determine the influence of sediment size on the shape of the scour, it is necessary to observe the topographic map of the scour under different sediment sizes at the same flow rate. Figure (a) of Figures 4-7 shows the topographic map of various sediment sizes after scouring stability at a flow rate of 400.48 
$\mathrm{m}^{3} / \mathrm{s}$. Similarly, (b), (c), and (d) in Figures 4-7 show four kinds of particles under the flow of $345.36 \mathrm{~m}^{3} / \mathrm{s}, 291.34 \mathrm{~m}^{3} / \mathrm{s}$ and $249.46 \mathrm{~m}^{3} / \mathrm{s}$, respectively. Figure 11 shows the various sediment sizes corresponding to the flow rates of $400.48 \mathrm{~m}^{3} / \mathrm{s}$ and $345.36 \mathrm{~m}^{3} / \mathrm{s}$. The left and right longitudinal scour profile of each different particle sizes under flow rate $\mathrm{Q}_{1}=400.48 \mathrm{~m}^{3} / \mathrm{s}$ (a) and $\mathrm{Q}_{2}=345.36 \mathrm{~m}^{3} / \mathrm{s}$ are shown in Figure 12 and Figure 13, respectively.

By comparing these figures, the depth and lateral range of the scour increase with the decrease of the particle size of the sediment. In contrast, the depth and range of the scour become smaller as the sediment size increases. The main reason is that the larger sediment size, the larger incipient velocity. As the sediment size on the riverbed increases, the initial scour velocity increases, so the riverbed is not easily washed away and the ability to punch is enhanced. Therefore, the depth and lateral range of local scour after the sluice are reduced as the sediment size increases. Hence, it can be concluded that the impact capacity of the riverbed and the local scour behind the sluice have a very great relationship.

At the same time, the upstream and downstream slopes of the scour hole formed under the same flow rate of different sediment sizes are similar. It is because, in the same flow rate, the flow velocity in the mainstream is relatively similar, which further explains that the flow velocity is the most important factor affecting the slope of the scour hole.

\section{Discussion of Scour Morphology}

\subsection{Plane Form}

The shape of the scour downstream varies widely compare to the complete scour (the deepest point of the scour hole was located in the center of the river bed), the plane shape was generally irregular ellipse or semi-ellipse (as can be seen from the topographic map in Figure 4). The upstream of the scour hole near the apron was steeper while the downstream of the scour hole was more gradual. It can also be observed from the topographic maps shown in Figures 4-7 that the planar shape of the scour hole was not a fixed appearance, because when it was affected by special terrain or water flow factors, the shape of the scour will change. The topographic map after the completion of a certain flush in the test is as shown in Figure 14. The scour hole was heavily biased to the side of the river

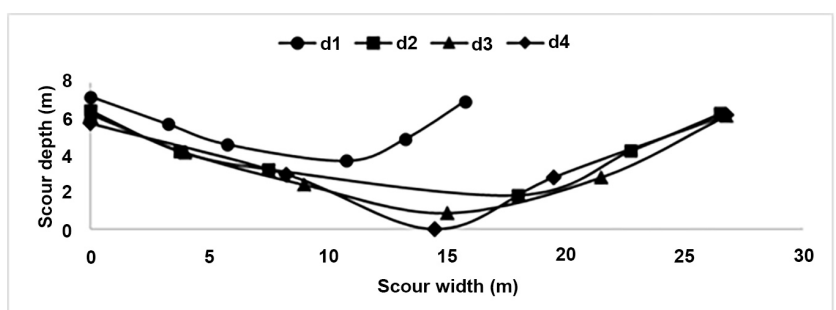

(a)

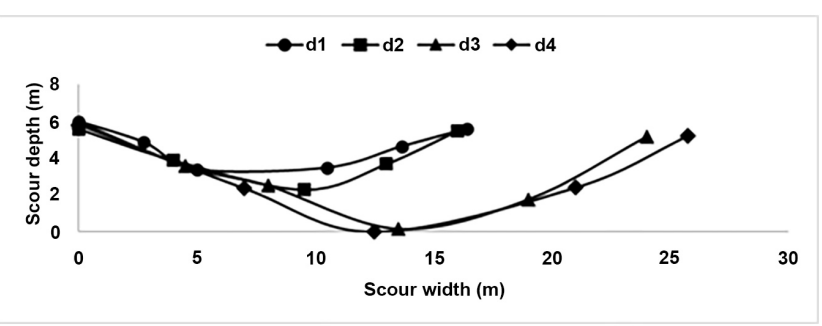

(b)

Figure 11. Cross-section of local scour downstream of each different particle sizes under flow rate $\mathrm{Q}_{1}=400.48 \mathrm{~m}^{3} / \mathrm{s}(\mathrm{a})$ and $\mathrm{Q}_{2}=$ $345.36 \mathrm{~m}^{3} / \mathrm{s}(\mathrm{b})$. 


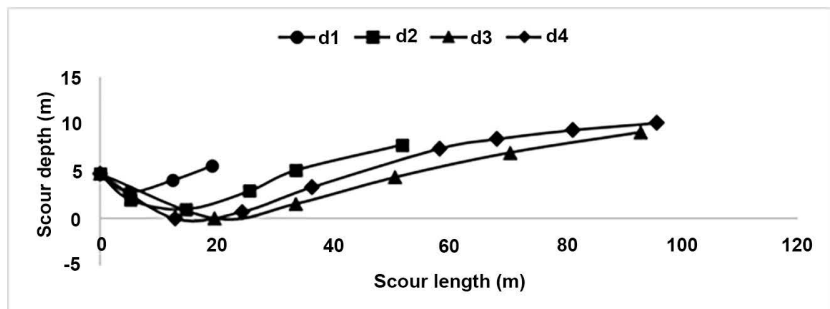

(a)

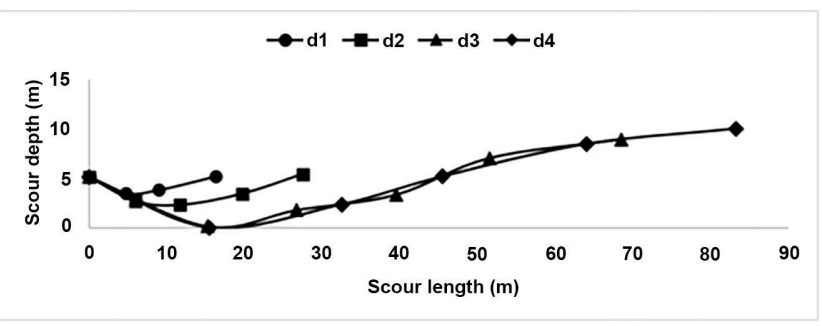

(b)

Figure 12. Left longitudinal scour profile of each different particle sizes under flow rate $\mathrm{Q}_{1}=400.48 \mathrm{~m}^{3} / \mathrm{s}(\mathrm{a})$ and $\mathrm{Q}_{2}=345.36 \mathrm{~m}^{3} / \mathrm{s}$ (b).

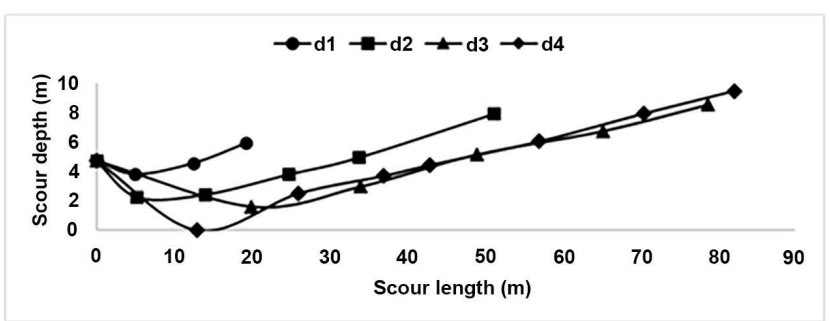

(a)

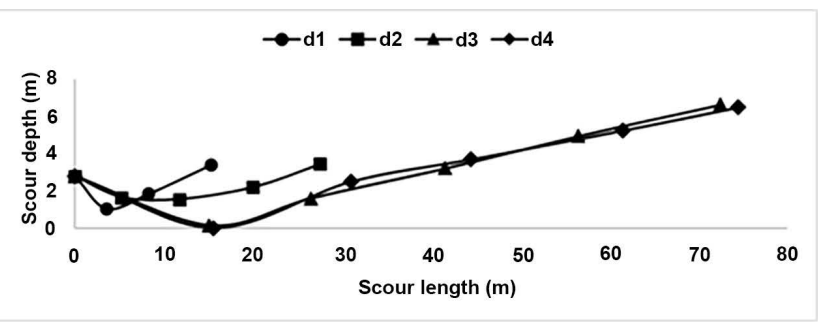

(b)

Figure 13. Right longitudinal scour profile of each different particle sizes under flow rate $\mathrm{Q}_{1}=400.48 \mathrm{~m}^{3} / \mathrm{s}(\mathrm{a})$ and $\mathrm{Q}_{2}=345.36$ $\mathrm{m}^{3} / \mathrm{s}(\mathrm{b})$.

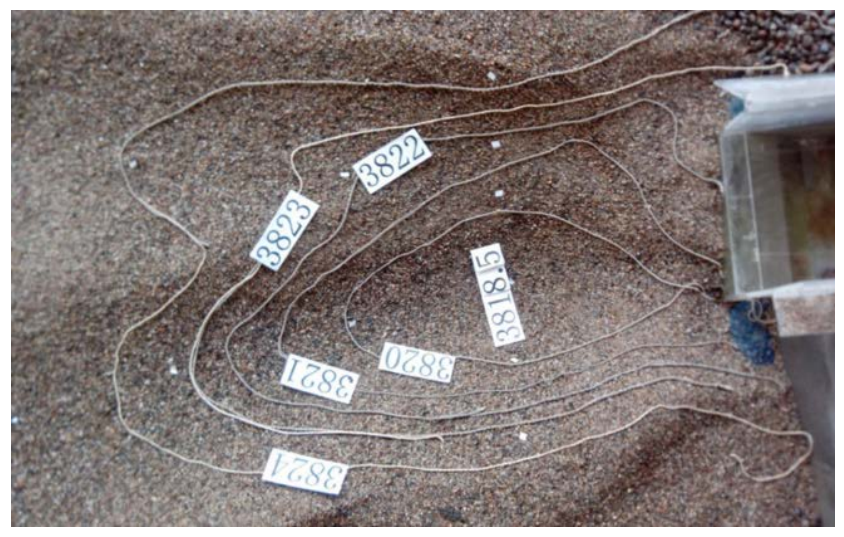

Figure 14. One of the local scour downstream in the experiment.

bank or two scour holes were biased to the sides of the river. Due to the ununiform velocity distribution, some downstream rivers had a deep point except for the deepest point of a scour hole.

The average flow velocity distribution of each measuring point on the section has been relatively uniform, but the actual flow due to the internal turbulence phenomenon, resulting in unbalanced fluctuating pressure and made the boundary of the scouring riverbed constantly changing, and so on. It is still difficult to maintain true binary water flow properties. The actual water flow was affected by various factors and eventually formed a complex scouring hole in the downstream riverbed. Therefore, in order to further study the scouring process, it is necessary to start from the angle of the flow plane. By analyzing the lateral flow 
velocity distribution on the water flow plan, it can be seen that the swirling water flow was often generated on both sides of the main flow concentrated in the flow potential. The mainstream was biased to one side because of the asymmetry of backflow. In the mainstream bias on the left side, the lateral backflow range was forced to shrink, but the rotational speed was strengthened, the left riverbed sediment was washed, the right backflow range was relatively enlarged, but the spinning speed became smaller, resulting in siltation. At the same time, the mainstream carried a part of the sediment into the downstream. Then the backflow range changed due to the deformation of the riverbed on the left and right sides until the left and right backflow phases were balanced, and the mainstream returned to the middle. However, this balance of equilibrium was not be maintained for a long time, the mainstream was in the next moment biased to the right side, and then to the right riverbed to produce scour hole. In this way, the scouring on both sides was alternately advanced and deepened in the process of the mainstream constantly swaying until the water flow was stable and the scouring balance was stopped.

\subsection{Longitudinal Scour Profile}

From the longitudinal section along the river, the scouring generally had a concave arc shape where the upstream of the scouring hole near the apron was steeper, and the downstream of the scouring hole was more gradual. This phenomenon can also be seen in Figure 12 and Figure 13. This phenomenon was mainly due to the relatively large outflow velocity of the basin, and a relatively strong scouring was formed on the downstream riverbed, which soon developed a scour hole on the riverbed next to the apron. The sediment on the upstream slope of the scour hole moved upstream along the slope in the strong swirling action of the water flow, but some of it was carried downstream by the mainstream. However, the sediment on the downstream slope of the scour hole has been moving downstream at the bottom of the river, and the deepest point of the scour hole had gradually moved downstream, and the range of the scour hole was gradually increased until the upper and lower slopes of the scour hole gradually slow down and the scouring reached to equilibrium.

In general, there was a scour hole in the longitudinal direction. Sometimes, a small pile of mounds was formed behind the scour hole due to the accumulation of sediment in the downstream of the scour hole, and a smaller one was formed behind the pile of mounds due to the flow of water. However, as the water flow has been flattening, the formed craters were small and shallow.

From the analysis of the test process and the test results, it was known that as the discharge flow increased and the flow velocity increased, the farther distance from the lowest point of the scour hole to the end of apron, the deeper the scour depth. The size, shape, location, depth and development direction of the largest scour hole was controlled by many factors. The sand composition of the downstream bed was different and the ununiform distribution of the flow velocity affected the distribution and change of the scour. Generally, the side with a faster 
Table 5. The upstream and downstream slope gradient of the scour hole in the test.

\begin{tabular}{cccc}
\hline $\mathrm{Q}\left(\mathrm{m}^{3} / \mathrm{s}\right)$ & $\mathrm{D}(\mathrm{mm})$ & $\begin{array}{c}\text { Upstream of the scour } \\
\text { hole average slope }\end{array}$ & $\begin{array}{c}\text { Average slope scour } \\
\text { hole downstream }\end{array}$ \\
\hline 400.48 & 500 & $1 / 3$ & $1 / 5$ \\
345.36 & 500 & $1 / 3$ & $1 / 5$ \\
291.34 & 500 & $1 / 4$ & $1 / 4$ \\
249.46 & 500 & $1 / 4$ & $1 / 4$ \\
400.48 & 300 & $1 / 5$ & $1 / 6$ \\
345.36 & 300 & $1 / 4$ & $1 / 6$ \\
291.34 & 300 & $1 / 5$ & $1 / 7$ \\
249.46 & 300 & $1 / 3$ & $1 / 5$ \\
400.48 & 100 & $1 / 4$ & $1 / 9$ \\
345.36 & 100 & $1 / 4$ & $1 / 7$ \\
291.34 & 100 & $1 / 4$ & $1 / 8$ \\
249.46 & 100 & $1 / 4$ & $1 / 7$ \\
400.48 & 50 & $1 / 3$ & $1 / 9$ \\
345.36 & 50 & $1 / 4$ & $1 / 8$ \\
291.34 & 50 & $1 / 4$ & $1 / 7$ \\
249.46 & 50 & $1 / 4$ & $1 / 7$ \\
\hline & & & \\
\hline
\end{tabular}

flow velocity was easier to form the scour earlier and faster. Through the observation of the development process of the lateral scour shape during the test, it was found that although the cross-sectional dimension of the scour was continuously developed as the scouring progresses but the slope angle didn't change much. According to the analysis of the main scouring stage, the ratio of the horizontal distance from the end of apron to the maximum depth of the scourhole was not changed much, but the downstream side slope was developing downstream before reaching the scouring equilibrium. The change of the shape of the scour was the result of the combined action of the sediment movement of the riverbed and the collapse of the slope of scour.

The average upstream slope of the scour hole plays an important role in judging the impact of the scour on the safety of the dam. In order to more accurately study the shape of the scour hole, the upstream and downstream slopes of the scour hole were recorded as shown in Table 5. The average slopes of the upstream and downstream scour tests were substantially in the range of $1 / 3 \sim 1 / 5$ and the range of $1 / 4$ to $1 / 9$, respectively. According to the experimental data, Mao Yuxi's range was roughly $1 / 3$ to $1 / 6$ of the upstream slope of the scour hole and the downstream slope was about $1 / 10$. The test results in this experiment are in good agreement with the experimental results of the previous study [5].

\section{Conclusion}

The physical model tests were conducted to study the local scouring downstream 
of an apron of Dangka hydropower station and some conclusions were shown as follows. The plane shape of the scour hole kept similar during the scouring process, i.e. irregular ellipse or semi-ellipse. The depth and size of the scour hole increased with the increase of the flow rate and decreased with the increase of the sediment size. Moreover, the downstream longitudinal slope ratio of the scour increased with the increase of the sediment size. The upstream and downstream slope coefficients of the local scour hole were $1 / 2$ to $1 / 6$ and about $1 / 10$, respectively. In the design and operation, the safety slope coefficient of a scour can be determined. Hence, the scour in this range will not endanger the safety of the building. This paper strengthens the experimental study of local scour downstream of an apron and it could be data of validation of the numerical study in future research.

\section{Funding}

This research was supported by the National Natural Science Foundation of China (Grant No. 51879227, No. 51279170).

\section{Conflicts of Interest}

The authors declare no conflicts of interest regarding the publication of this paper.

\section{References}

[1] Zheng, H.Y., et al. (2006) Research on Low Water Head Energy Dissipation and Impact Test. Water Resources and Hydropower Engineering Design, 25, 2-4. (In Chinese)

[2] Yan, X.D., et al. (1990) Low Head Water Diversion and Sand Control Hub. Water Power Press, Beijing. (In Chinese)

[3] Wu, G.J. (2011) Upstream Local Scour of Low-Head Hydro-Junction. Changsha University of Science and Technology, Changsha. (In Chinese)

[4] Department of Hydraulics, T.U. (1983) Hydraulics (Upper and Lower Volumes). People's Education Press, Beijing. (In Chinese)

[5] Mao, Y.X., et al. (1995) Hydraulic and Design Management of Dam Engineering. Water Power Press, Beijing. (In Chinese)

[6] Nik Hassan, N.M.K. and Narayanan, R. (1985) Local Scour Downstream of an Apron. Journal of Hydraulic Engineering, 111, 1371-1385. https://doi.org/10.1061/(ASCE)0733-9429(1985)111:11(1371)

[7] Gisonni, C. and Rasulo, G. (1997) Local Scouring Downstream of Positive Step Stilling Basins. Proceedings of the 199727 th Congress of the International Association of Hydraulic Research, San Francisco, 10-15 August 1997, 423-428.

[8] Jin, G. and Gao, P. (1988) Mathematical Model of River Bed Scouring Downstream of Stilling Basin. Journal of Hydraulic Engineering, 114, 9-16.

[9] Shafai-Bajestan, M., Sayahi, A. and Albertson, M.L. (1994) Scour Hole Depth Downstream of the SAF Stilling Basin. Proceedings of the 1994 ASCE National Conference on Hydraulic Engineering, Buffalo, 1-5 August 1994, 1045-1049.

[10] Zhang, G., et al. (2017) 2D Numerical Simulation on the Local Scour Pit Down- 
stream of Hengdan Hydropower Station. Journal of Basic Science and Engineering, $25,1139-1146$.

[11] Sassa, N., et al. (2018) Effect of Three-Dimensional Flow Structure on Generation Mechanism of Large-Scale Local Scouring in the Kiso River. 21 st Congress of International Association for Hydro-Environment Engineering and Research-Asia Pacific Division: Multi-Perspective Water for Sustainable Development, Yogyakarta, 2-5 September 2018, 155-163.

[12] Xie, C. and Lim, S.-Y. (2015) Effects of Jet Flipping on Local Scour Downstream of a Sluice Gate. Journal of Hydraulic Engineering, 141, Article ID: 04014088. https://doi.org/10.1061/(ASCE)HY.1943-7900.0000983

[13] Jahromi, S.H.M. and Nasserian, H.H. (2010) Effect of Tail-Water Depth on the Scour Downstream of Falling Jets. 5th International Conference on Scour and Erosion, San Francisco, 7-10 November 2010, 688-696.

https://doi.org/10.1061/41147(392)67

[14] Kells, J.A., Balachandar, R. and Hagel, K.P. (2001) Effect of Grain Size on Local Channel Scour below a Sluice Gate. Canadian Journal of Civil Engineering, 28, 440-451. https://doi.org/10.1139/101-012

[15] Fan, F., et al. (2017) Numerical Investigation of the Influence of Water Jumping on the Local Scour beneath a Pipeline under Steady Flow. Water (Switzerland), 9, 642. https://doi.org/10.3390/w9090642

[16] Tominaga, A. and Sadat, S.H. (2016) Combination of Permeable and Impermeable Spur Dikes to Reduce Local Scour and to Create Diverse River Bed. 13th International Symposium on River Sedimentation, Stuttgart, 19-22 September 2016, 450-456.

[17] Si, J.-H., Lim, S.-Y. and Wang, X.-K. (2019) Jet-Flipping in Scour Hole Downstream of Unsubmerged Weir with Apron. Journal of Hydraulic Engineering, 145, Article ID: 04019035. https://doi.org/10.1061/(ASCE)HY.1943-7900.0001634

[18] Kumala, Y.E., Lestari, S. and Zulfan, J. (2018) Study to Minimize the Local Scour Downstream of Stilling Basin. 21st Congress of International Association for $\mathrm{Hy}^{-}$ dro-Environment Engineering and Research, Yogyakarta, 2-5 September 2018, 115-122.

[19] Aminpour, Y., et al. (2018) Characteristics and Time Scale of Local Scour Downstream Stepped Spillways. Scientia Iranica, 25, 532-542.

[20] Guo, H.H. and Zhang, G.G. (2010) Three-Dimensional Numerical Simulation of Overflow Weir at Jiulongxia Hydropower Station. Journal of the Yangtze River Scientific Research Institute, 27, 34-37. (In Chinese)

[21] Gao, J.Y. (2013) Three-Dimensional Flow Field Simulation of Hengdan Hydropower Station and Hydraulic Characteristics of Downstream Two-Dimensional Scouring Pit. Northwest A\&F University, Yang Ling. (In Chinese)

[22] Shi, Z.P. (2010) Numerical Simulation of Energy Dissipation Measures for Low-Head Draining Buildings. Northwest A\&F University, Yang Ling. (In Chinese)

[23] Adduce, C. and Sciortino, G. (2006) Scour Due to a Horizontal Turbulent Jet: Numerical and Experimental Investigation. Journal of Hydraulic Research, 44, 663-673. https://doi.org/10.1080/00221686.2006.9521715

[24] Espa, P. and Sibilla, S. (2014) Experimental Study of the Scour Regimes Downstream of an Apron for Intermediate Tailwater Depth Conditions. Journal of Applied Fluid Mechanics, 7, 611-624.

[25] Adduce, C. and Rocca, M. (2006) Local Scouring Due to Turbulent Water Jets 
Downstream of a Trapezoidal Drop: Laboratory Experiments and Stability Analysis. Water Resources Research, 42, 67-80. https://doi.org/10.1029/2005WR004139

[26] Zhang, G.G., et al. (2013) Hydraulic Overall Model Test of Yushu Dangka Hydropower Station Project in Qinghai. (In Chinese) 